\title{
ANALISIS BIAYA PRODUKSI PETERNAKAN AYAM PETELUR DI KABUPATEN TULUNGAGUNG (Studi Kasus di Dofir Layer Farm)
}

\author{
Zeni Budi Santoso ${ }^{1)}$, Eddy Trijana Sudjani ${ }^{2)}$, Adi Andaka ${ }^{2)}$ \\ ${ }^{1)}$ Mahasiswa Program Studi Ilmu Ternak Fakultas Peternakan \\ ${ }^{2)}$ Dosen Program Studi Ilmu Ternak Fakultas Peternakan \\ Universitas Islam Balitar \\ Jl. Majapahit No. 04 Kota Blitar
}

\begin{abstract}
This research was conducted at the lender Layer Farm owned by H. Dofir located in the village Rejotangan Rejotangan Tulungagung subdistrict. The aim was to determine the analysis of financial analysis in laying hens at the DLF Rejotangan Tulungagung subdistrict, It examines some of the financial aspects of the financial analysis used are, Net B/C Ratio, Net Present Value (NPV), Internal Rate of Return (IRR), Payback Period (PP) and Switchings Value. Based on the results of the calculation of financial feasibility of the business laying on Dofir Layer Farm then obtained when the initial conditions of business where there has been no increase productivity showed NPV greater than 0, namely Rp 2,359,608,260.73 IRR is greater than the discount rate that is equal to 71 percent, Net $\mathrm{B} / \mathrm{C}$ of 3.28 is greater than one, $\mathrm{PP}$ is shorter than the life of the project is 2 years and 3 months. Business sensitivity analysis is feasible because decrease of production by 26 percent, the price increase of 28.6 percent DOC and feed prices rise by 37 percent NPV indicates value greater than zero, the Net B/C is greater than 1, IRR more greater than the discount rate and the PP before the age of the business end. In the conditions of development of the results obtained from the analysis showed that this business is financially feasible when done business development by improving the productivity of laying chicken
\end{abstract}

Keyword : poultry, financial and business.

\section{PENDAHULUAN}

Pada saat sekarang ini kehidupan masyarakat sangat sulit jangankan untuk memenuhi kebutuhan sekunder, untuk memenuhi kebutuhan primer saja masyarakat sudah sangat kesulitan. Untuk itu diperlukan adanya perbaikan perekonomian masyarakat. Salah satu faktor yang perlu diperhatikan adalah sektor pertanian karena sektor pertanian adalah sektor yang sangat penting peranannya dalam perkonomian. Soekartawi (2002) menyatakan bahwa sektor pertanian di Indonesia dianggap penting. Hal ini terlihat dari peranan sektor pertanian terhadap penyediaan lapangan kerja, penyediaan pangan dan penyumbang devisa negara yaitu melalui ekspornya.

Peran sub sektor peternakan terhadap pembangunan pertanian cukup signifikan, dimana industri perunggasan merupakan pemicu utama perkembangan usaha di sub sektor peternakan. Permintaan pangan hewani asal ternak (daging, telur dan susu) dari waktu ke waktu cenderung meningkat sejalan dengan pertambahan jumlah penduduk, pendapatan, kesadaran gizi, dan perbaikan tingkat pendidikan. Sehingga pengembangan peternakan mempunyai harapan yang baik dimasa depan karena permintaan bahan-bahan berasal dari ternak akan terus meningkat seiring dengan meningkatnya jumlah penduduk, peningkatan pendapatan dan peningkatan kesadaran masyarakat untuk mengkonsumsi pangan yang bergizi tinggi. Hal ini dapat mendukung mewujudkan program pemerintah yaitu percepatan pemulihan ekonomi melalui 
pemberdayaan dan peningkatan sistem ekonomi kerakyatan. Mubyarto (2000) menyatakan bahwa pemberdayaan adalah usaha untuk membangun daya (masyarakat) dengan mendorong, memotivasi dan membangkitkan kesadaran akan potensi yang dimiliki serta berupaya untuk mengembangkannya. Sodiq (2012) menjelaskan bahwa ekonomi rakyat adalah kegiatan ekonomi yang diselenggarakan oleh kebanyakan rakyat Indonesia dan pada umumnya terdiri atas koperasi, pengusaha mikro, pengusaha kecil dan menengah, sedangkan ekonomi kerakyatan adalah sistem ekonomi yang berorientasikan pada peningkatan partisipasi produktif masyarakat dalam penyelenggaraan ekonomi.

Pelaksanaan ekonomi kerakyatan lebih diarahkan pada upaya optimalisasi potensi setiap wilayah berdasarkan kondisi sumber daya alam, manusia, lingkungan, kreatifitas dan komoditi di daerah tersebut. Perkembangan suatu komoditi ditentukan antara lain oleh peranan dan permintaan akan komoditi tersebut, peningkatan pendapatan masyarakat juga berpengaruh terhadap permintaan (Supadi dan Nurmanaf, 2008). Ayam ras petelur merupakan salah satu jenis ternak unggas yang cukup berkembang di Jawa Timur. Menurut data statistik Peternakan (2014), populasi ayam ras petelur di Jawa Timur sekitar 30\% dari total keseluruhan populasi ayam ras petelur di Indonesia. Usaha peternakan ayam petelur merupakan usaha yang dapat menghasilkan perputaran modal yang cepat dan harga telurnya yang relatif murah sehingga mudah terjangkau oleh lapisan masyarakat.

Kabupaten Tulungagung merupakan salah satu kawasan peternakan ayam petelur di Jawa Timur yang masih membutuhkan pengembangan. Kawasan Kabupaten Tulungagung sangat potensial sebagai daerah peternakan unggas. Umumnya ternak yang dipelihara di daerah kabupaten Tulungagung adalah ayam ras petelur. Sedangkan tingkat perkembangan populasi ayam petelur di Kabupaten Tulungagung tersebar hampir secara merata namun yang terbanyak adalah di Kecamatan Rejotangan. Berdasarkan data Statistik Kabupaten Tulungagung pada tahun 2013 ada 102 peternakan ayam petelur atau pedaging. Dibandingkan tahun 2012 secara umum populasi ternak mengalami peningkatan. Peningkatan populasi ternak tertinggi ada pada jenis ternak ayam ras, baik petelur maupun pedaging. Secara total ternak Ayam Ras meningkat sangat fantastis, yakni $88,06 \%$. Peningkatan yang tinggi tersebut ditopang oleh ternak ayam ras petelur yang meningkat hingga $124 \%$. Peningkatan ini disebabkan permintaan yang cukup tinggi dari daerah-daerah sekitar Kabupaten Tulungagung (BPS Kabupaten Tulungagung, 2014).

Daerah peternakan di Kabupaten Tulungagung umumnya berada di Kecamatan Ngunut, Rejotangan, Boyolangu dan Sumbergempol. Dari kelima kecamatan tersebut populasi ayam ras petelur terbanyak adalah di Kecamatan Rejotangan. Kecamatan Rejotangan merupakan daerah di Kabupaten Tulungagung yang memiliki potensial tinggi untuk pengembangan usaha ternak ayam ras petelur. Salah satu perusahaan lokal yang melakukan usaha peternakan ayam ras petelur adalah Dofir Layer Farm (DLF). Dofir Layer Farm merupakan peternakan ayam ras petelur yang terletak di Desa Rejotangan. Selain memiliki tempat yang strategis, DLF juga mempunyai pasar yang cukup luas. Banyaknya jumlah permintaan telur setiap hari yang tidak dapat dipenuhi oleh DLF menjadi peluang untuk perusahaan dalam mengembangkan usahanya serta melakukan analisis kelayakan usaha telur ayam ras ketika dilakukan penambahan jumlah produksi dalam memenuhi permintaan konsumen. Untuk melakukan hal tersebut DLF melakukan perubahan struktur kandang ayam agar dapat menampung lebih banyak ayam ras petelur dan dapat mengefisienkan lahan yang digunakan. Berdasarkan uraian diatas , maka perlu dilakukan analisis kelayakan pada usaha telur ayam ras di DLF baik usaha yang sedang dijalani sekarang maupun rencana usaha yang akan dikembangkan. Analisis usaha ini dilakukan untuk mengetahui apakah usaha telur ayam ras tersebut layak jika dilihat dari aspek finansial. 


\section{MATERI DAN METODE PENELITIAN}

Metode penelitian yang digunakan adalah metode studi kasus dan pengamatan terhadap peternakan ayam ras petelur milik H. Dofir. Metode pengambilan sampel dengan metode pengamatan secara langsung.

\section{Pengumpulan Data}

Data yang digunakan adalah data primer dan data sekunder. Data primer adalah informasi yang diperoleh peneliti secara langsung di tempat penelitian atau di suatu tempat yang menjadi obyek penelitian, sedangkan data sekunder adalah sata-data yang dikumpulkan secara tidak langsung dari sumber-sumber lain misalnya buku, jurnal atau dari lembaga terkait.

\section{Analisis Data}

1. Analisa deskriptif untuk mengetahui keadaan usaha peternakan dan karakteristik peternak ayam petelur.

2. Analisa ekonomi meliputi

Aspek keuangan atau finansial bertujuan untuk mengetahui perkiraan dalam hal pendanaan dan aliran kas, sehingga dapat diketahui layak atau tidaknya bisnis yang dijalankan. Metode yang dapat digunakan dalam kajian ini adalah metode analisis kelayakan bisnis. Aspek finansial ini mengkaji beberapa analisis kelayakan finansial yang digunakan yaitu, Net B/C Ratio Net Present Value (NVP), Internal Rate of Return (IRR), Payback Period (PP) dan Switchings Value.

\section{HASIL DAN PEMBAHASAN \\ Analisis Finansial}

Analisis kelayakan finansial dalam penelitian ini ditujukan untuk mengetahui kelayakan usaha peternakan ayam ras petelur dari segi keuangan. Analisis finansial digunakan dengan menggunakan kriteria-kriteria penilaian kelayakan yaitu NPV, IRR, Net B/C dan Payback Period, dan Sensitivitas. Untuk menganalisis kriteria tersebut menggunakan arus kas (cashflow).Selain itu juga akan dilakukan analisis laba rugi yang akan menghasilkan komponen pajak yang merupakan pengurangan dalam cashflow perusahaan.

\section{Analisis Kelayakan Kondisi Awal}

Pada Kondisi Awal ini H. Dofir Farm (DLF) mengusahakan 13.000 ekor ayam ras petelur untuk dijadikan ayam petelur. Pemenuhan jumlah ayam petelur yang dilakukan diusahakan 100 persen diperoleh dengan membeli dari produsen bibit atau DOC yaitu PT.Sierat,Tbk seharga Rp 3.500,00 per ekor dengan umur DOC nol hari (starter). DOC dibesarkan di kandang starter sampai berumur satu bulan, kemudian dipindahkan ke kandang grower. Pada kondisi ini , menunjukkan keadaan usaha ketika belum melakukan pengembangan usaha atau penambahan jumlah kapasitas ayam ras petelur.

\section{Arus Penerimaan}

Penerimaan adalah segala sesuatu yang dapat meningkatkan pendapatan sebuah bisnis. Arus manfaat bisnis ini adalah penerimaan dari hasil penjualan telur ayam ras, ayam petelur afkir dan kotoran ayam dan nilai sisa.

\section{Penerimaan Penjualan Telur Ayam}

Jumlah ayam ras petelur yang diusahakan oleh DLF sebanyak 13.000 ekor dimana setiap ayam petelur mampu menghasilkan satu butir telur per hari. Telur ayam dijual dalam satuan kilogram yang dikemas dalam sebuah peti yang berisi 15 kilogram telur ayam. Penerimaan merupakan hasil dari penjualan telur ayam yang tergantung dari harga pasar saat itu. Selengkapnya hasil penjualan dapat di lihat pada tabel 1. 
Tabel 1. Penerimaan Penjualan Telur Ayam.

\begin{tabular}{|c|c|c|c|c|c|c|c|}
\hline \multirow{2}{*}{$\begin{array}{c}\text { Populasi } \\
\text { Ayam }\end{array}$} & \multicolumn{3}{|c|}{ Produksi Telur } & \multicolumn{4}{c|}{ Penjualan } \\
\cline { 2 - 8 } & Persentase & Butir & $\begin{array}{c}\text { Berat } \\
\text { Telur }\end{array}$ & $\begin{array}{c}\text { Harga } \\
/ \mathrm{Kg}\end{array}$ & $\begin{array}{c}\text { Berat } \\
/ \text { Peti }\end{array}$ & $\begin{array}{c}\text { Harga } \\
/ \text { Peti }\end{array}$ & $\begin{array}{c}\text { Telur } \\
\text { Kurang } \\
\text { Baik }\end{array}$ \\
\hline $\begin{array}{c}13,000 \\
\text { ekor }\end{array}$ & $90 \%$ & $\begin{array}{c} \pm \\
11,700\end{array}$ & $\begin{array}{c}40-80 \\
\text { gram }\end{array}$ & $\begin{array}{c}\mathrm{Rp} \\
13,200\end{array}$ & $\begin{array}{c}15 \\
\mathrm{~kg}\end{array}$ & $\begin{array}{c}\mathrm{Rp} \\
198,000\end{array}$ & $\begin{array}{c}\text { Rp } \\
11,000\end{array}$ \\
\hline \multicolumn{3}{|c|}{ Jumlah penerimaan pada tahun pertama } & \multicolumn{3}{c|}{ RP 623,700,000 } \\
\hline
\end{tabular}

Sumber : Data yang diolah 2015

\section{a. Penerimaan Penjualan Ayam Afkir}

Penerimaan penjualan ayam petelur afkir adalah penerimaan sampingan yang dihasilkan pada saat periode pemeliharaan berakhir. Penerimaan penjualan Ayam petelur afkir mulai diperoleh pada awal tahun ke-3. Pada umumnya ayam petelur afkir banyak dicari pelanggan untuk dijadikan ayam potong yang memiliki nilai ekonomis cukup tinggi sehingga dapat dijual. Nilai jual ayam petelur afkir yaitu Rp30.000 per ekor. Adapun total nilai penerimaan dari penjualan ayam afkir sebesar Rp312.000.000,00. Dari 13.000 ekor ayam yang diusahakan diperkirakan hidup hingga akhir tahun kedua umur produksi ayam yaitu sekitar 80 persen atau sama dengan 10.400 ekor ayam.

\section{b. Penerimaan Penjualan Kotoran Ayam}

Penerimaan penjualan kotoran ayam petelur juga merupakan penerimaan sampingan yang memberikan manfaat cukup besar terhadap keuntungan perusahaan. Kotoran ayam dijual dalam bentuk karung dengan harga Rp 4.500,00 per karung. Kotoran ayam banyak dicari petani karena harganya yang cukup terjangkau untuk dijadikan pupuk kompos. Adapun total nilai penerimaan dari penjualan kotoran ayam sebesar Rp 8.100.000,00 pada tahun pertama dan Rp 54.000.000,00 tahun berikutnya. DLF dalam sebulan mampu menghasilkan lebih dari 1.000 karung kotoran ayam.

\section{c. Nilai Sisa}

Penerimaan nilai sisa adalah penerimaan yang diperoleh dari sisa modal investasi yang tidak terpakai habis selama umur usaha. Investasi yang memberikan nilai sisa pada usaha peternakan telur ayam ras DLF adalah nilai tanah, bangunan, mesin, dan kendaraan. Pada penelitian ini diperoleh nilai sisa investasi pada akhir tahun ke lima adalah Rp 22.560.000,00.

\subsubsection{Arus Pengeluaran (Outflow)}

Komponen biaya dikelompokkan menjadi dua bagian yaitu investasi dan biaya operasional. Biaya investasi adalah biaya yang harus dikeluarkan pada awal tahun usaha atau pada saat usaha telah berlangsung untuk mendapatkan faktor-faktor produksi yang digunakan dalam proses produksi. Biaya operasional adalah sejumlah biaya yang dikeluarkan agar proses produksi dapat berlangsung.

\section{Biaya Investasi}

Biaya investasi adalah biaya yang dikeluarkan satu kali dalam satu periode proses produksi untuk memperoleh berapa kali manfaat secara ekonomis yang dikeluarkan pada awal kegiatan dan jumlahnya cukup besar. Biaya tanah dan bangunan adalah biaya pembangunan yang dibayarkan pada awal periode usaha. Dalam analisis keuangan ini diasumsikan umur usaha adalah 5 tahun. Peralatan memiliki nilai ekonomis satu hingga empat tahun, sehingga dibeberapa peralatan setiap tahunnya dilakukanp reinvestasi.

Perhitungan penyusutan dengan menggunakan metode garis lurus. Penyusutan adalah nilai harga beli dikurangi nilai sisa dibagi dengan umur ekonomis. Nilai penyusutan dimasukkan 
dalam perhitungan laba rugi dan nilai sisa dimasukkan dalam perhitungan pendapatan atau penerimaan. Jumlah biaya investasi dari usaha ini adalah sebesar Rp 694,420,000,00 dan nilai sisanya adalah $\mathrm{Rp} 22.560 .000,00$ dengan jumlah biaya penyusutan per tahunnya adalah $\mathrm{Rp}$ $95,872,166.67$.

\section{Biaya operasional}

Biaya operasional adalah biaya yang diperlukan untuk menjalankan kegiatan produksi. Biaya operasional terdiri dari biaya variable dan biaya tetap.

\section{Biaya tetap}

Biaya tetap adalah biaya yang dikeluarkan setiap tahun yang besarnya tidak terkait langsung dengan jumlah produksi dan akan dikeluarkan selama usaha itu berlangsung. Biaya yang dikeluarkan oleh DLF meliputi biaya gaji yang terdiri dari gaji kepala kandang, bagian administrasi, supir dan bagian produksi. Pemberian gaji dilakukan sebulan sekali dimana setiap bagian berbeda jumlahnya, selain gaji ada biaya rekening listrik dan telepon yang dibayar sebulan sekali dan dihitung dalam setahun yang diasumsikan cateris paribus. Biaya alat dan bangunan atau investasi yang diasumsikan lima persen dari total investasi, alat tulis kantor yang dibeli setiap bulannya digunakan untuk keperluan selama proses produksi dan panen.

Pajak Bumi Bangunan (PBB) dan Pajak mobil yang dibayarkan setahun sekali, BBM atau bahan bakar minyak. Bahan bakar minyak yang digunakan diperusahaan yaitu solar dan bensin. Solar digunakan untuk mesin disel yang menjalankan mesin penggiling pakan. Dalam satu kali penggilingan pakan perusahaan menggunakan tiga liter minyak solar, dimana dalam seminggu perusahaan melakukan penggilingan pakan sebanyak tiga kali produksi, sedangkan untuk bensin digunakan untuk mobil yang diperkirakan sehari 10 liter per hari. Harga bensin dan solar yang digunakan berlaku harga saat ini yaitu Rp 4.500,00 (cateris paribus).

\section{Biaya Variabel}

Biaya variabel adalah biaya yang dikeluarkan untuk keperluan produksi dan jumlahnya dipengaruhi oleh jumlah produksi. Biaya yang dikeluarkan diantaranya yaitu DOC, sekam dan koran bekas digunakan untuk alas lantai DOC dan alas peti kayu kemasan telur, karung bekas digunakan untuk kotoran ayam, pakan yang digunakan oleh perusahaan yaitu jagung, dedak, kulit kerang, konsentrat, ikan, insentif, gas untuk penghangat DOC, vaksin, obat-obatan dan desifektan. Gas elpiji yang digunakan untuk penghangat buatan DOC dalam satu siklus produksi digunakan sebanyak 180 tabung gas atau setara dengan 540 kilogram dimana penggunaan gas dilakukan mulai dari DOC umur nol hari.

Dalam sehari gas elpiji digunakan yaitu sebanyak 6 tabung, penghangat ini digunakan hingga DOC berumur 30 hari atau satu bulan. Dalam satu tahun ada 4 kali siklus produksi sehingga gas elpiji yang digunakan sebanyak 720 tabung gas. Biaya pakan terdiri dari jagung, dedak, kulit kerang, konsentrat, ikan dimana kuantitas pakan yang digunakan dalam sebulan yaitu jagung sebesar 14.000 kilogram dengan harga beli Rp 3.250,00 per kilogram, dedak 4.000 kilogram dengan harga beli Rp 2.000,00 per kilogram, kulit kerang 80 karung dengan harga beli Rp 3.000,00 per kilogram, konsentrat 14.000 kilogram dengan harga beli Rp 5.000,00 per kilogram dan ikan 3.000 kilogram dengan harga beli Rp 2.500,00 per kilogram. Pakan merupakan salah satu input utama, apabila salah satu campuran pakan dikurangi atau ditiadakan ketika melakukan penggilingan akan mengakibatkan stress pada ayam.

Selain biaya pakan, biaya obat-obatan dan vitamin sangat perlu diperhatikan. Ayam sangat mudah terserang penyakit sehingga setiap peternakan harus mengetahui jenis obatobatan dan vitamin yang digunakan, dan untuk menjaga kebersihan lingkungan peternakan serta kandang dari bakteri maka perlu melakukan penyemprotan secara teratur dengan 
menggunakan desikvektan. Pada tahun pertama biaya variabel yang digunakan setengah dari jumlah biaya pada tahun ke dua dan selanjutnya. Adapun biaya variabel yang digunakan oleh DLF dalam pengembangan usahanya dapat dilihat pada Tabel 2.

Tabel 2. Biaya Variabel Dofir Layer Farm.

\begin{tabular}{|c|c|c|c|c|c|}
\hline No. & Uraian & Satuan & Jumlah & $\begin{array}{l}\text { Harga } \\
\text { Satuan }\end{array}$ & Jumlah Pertahun \\
\hline 1 & & Ekor & 13.000 & 3.500 & 45.500 .000 \\
\hline 2 & Sekam & Karung & 360 & 1.200 & 432.000 \\
\hline 3 & Karung Bekas & Buah & 20.000 & 1.000 & 20.000 .000 \\
\hline 4 & Pakan & & & & \\
\hline & - $\quad$ Jagung & $\mathrm{Kg}$ & 14.000 & 3.250 & 546.000 .000 \\
\hline & - $\quad$ Dedak & $\mathrm{Kg}$ & 4.000 & 2.000 & 96.000 .000 \\
\hline & $\begin{array}{l}\text { Kulit } \\
\text { Kerang }\end{array}$ & Karung & 80 & 3.000 & 2.880 .000 \\
\hline & - $\quad$ Konsentrat & $\mathrm{Kg}$ & 14.000 & 5.000 & 840.000 .000 \\
\hline & - $\quad$ Ikan & $\mathrm{Kg}$ & 3.000 & 2.500 & 90.000 .000 \\
\hline 5 & Koran Bekas & $\mathrm{Kg}$ & 120 & 1.000 & 1.200 .000 \\
\hline 6 & Spidol & Buah & 2 & 5.000 & 120.000 \\
\hline 7 & Insentif & Orang & 17 & 50.000 & 9.000 .000 \\
\hline 8 & Vaksin & Liter & 20 & 20.000 & 400.000 \\
\hline 9 & Obat-Obatan & Pack & 100 & 17.500 & 1.750 .000 \\
\hline 10 & $\begin{array}{c}\text { Desinfektan } \\
\text { dan Antiseptik }\end{array}$ & Liter & 50 & 35.000 & 1.750 .000 \\
\hline 11 & Gas Elpiji & Tabung & 540 & 15.000 & 10.800 .000 \\
\hline \multicolumn{5}{|c|}{ TOTAL } & 1.679.788.000 \\
\hline
\end{tabular}

Sumber: H. Dofir Farm, 2015

\section{Kriteria Kelayakan (Cashflow) Usaha Peternakan Ayam Ras Petelur}

Analisis cashflow merupakan analisis arus kas yang digunakan untuk mengukur kelayakan suatu usaha. Adapun cashflow DLF dalam mengukur kelayakan usaha peternakan ayam ras petelur adalah sebagai berikut.

a. NPV merupakan nilai yang menggambarkan apakah nilai yang dihasilkan dengan discount rate sama per tahunnya layak untuk dikembangkan. Nilai NPV yang diperoleh dari usaha ayam ras petelur oleh H. Dofir Farm adalah sebesar Rp 2.359.608.260,73 atau lebih besar dari 0 maka usaha ayam petelur ini layak untuk dijalankan.

b. IRR merupakan nilai yang menggambarkan tingkat pengembalian modal bagi pemilik perusahaan yang melakukan investasi selama proyek berlangsung. Nilai IRR yang diperoleh dari usaha ayam ras petelur oleh perusahaan adalah sebesar 71 persen atau lebih besar dari tingkat discount rate 6 persen, maka usaha ini layak untuk dijalankan

c. Net $\mathrm{B} / \mathrm{C}$ mengambarkan berapa besar keuntungan yang dapat dicapai jika mengeluarkan biaya sebesar Rp1,00. Nilai Net B/C yang diperoleh dari usaha ayam ras petelur oleh perusahaan adalah sebesar 3,28 atau lebih besar dari satu, artinya setiap pengeluaran sebesar RP 1,00 akan memperoleh manfaat bersih sebesar Rp 3,28.

d. Payback periode menunjukkan waktu pengembalian modal yang akan digunakan untuk melaksanakan pengembalian bisnis usaha ayam ras petelur. Nilai PP yang diperoleh dari usaha ayam ras petelur oleh perusahaan adalah 2,3 berarti tingkat pengembalian 
modal investasi pada usia usaha 2 tahun 3 bulan. Waktu pengembalian ini lebih rendah dari umur usaha, maka pengembangan bisnis ini layak untuk dijalankan.

\section{Analisis Laba Rugi}

Perhitungan laba rugi per tahun digunakan untuk melihat pendapatan bersih setelah dikurangi nilai bunga dan pajak. DLF tidak menggunakan bunga karena DLF tidak meminjam uang dari lembaga keuangan manapun atau biaya sendiri. Sedangkan hitungan pajak berdasarkan ketentuan undang-undang perpajakan yang mengenakan pajak sebesar 25 persen per tahun. Perhitungan laba rugi dapat dilihat pada tabel 3. Hasil perhitungan laba rugi bagian pajak dimasukkan kedalam cashflow sebagai pajak penghasilan atau $\mathrm{PPh}$.

Tabel 3. Analisis Rugi Laba Peternakan H. Dofir

\begin{tabular}{|l|c|}
\hline Uraian & Rataan Biaya (Rp/tahun) \\
\hline Penerimaan & 2.910 .600 .000 \\
\hline Penjualan telur ayam & 312.000 .000 \\
\hline Penjualan ayam afkir & 54.000 .000 \\
\hline Penjualan limbah peternakan & $\mathbf{3 . 2 7 6 . 6 0 0 . 0 0 0}$ \\
\hline Total Penerimaan & 347.132 .166 \\
\hline & 1.679 .788 .000 \\
\hline Biaya Variabel & $\mathbf{2 . 0 2 6 . 9 2 0 . 1 6 6}$ \\
\hline Biaya Tetap & \\
\hline Total Biaya & $\mathbf{1 . 2 4 9 . 6 7 9 . 8 3 4}$ \\
\hline
\end{tabular}

Sumber: H. Dofir Farm, 2015

\section{KESIMPULAN DAN SARAN Kesimpulan}

Hasil analisis aspek finansial berdasarkan kriteria kelayakan investasi menunjukkan bahwa usaha ini layak untuk dijalankan. Hal ini dikarenakan nilai NPV sebesar Rp 2.359.608.260,73 lebih besar dari nol, nilai net B/C sebesar 3,28 lebih besar dari satu, nilai IRR sebesar 71 persen lebih besar dari tingkat discount rate yang ditentukan, dan PP berada sebelum masa proyek berakhir yaitu 2 tahun 3 bulan. Hasil analisis sensitivitas menunjukkan bahwa usaha peternakan ayam ras petelur di H. Dofir Farm masih tetap layak dijalankan dan mendapatkan keuntungan apabila penurunan produksi sebesar 26 persen dan tidak lebih dari 37,1 persen dimana pada kondisi ini usaha megalami titik impas. Kenaikan harga pakan konsentrat sebesar 37 persen membuat perusahaan masih tetap mendapatkan keuntungan. Kenaikan harga pakan sebaiknya tidak lebih dari 76,2 persen dimana perusahaan mengalami titik impas. Kenaikan harga DOC tidak berpengaruh besar dengan kegiatan usaha tetapi harus tetap diperhatikan. Pada saat harga DOC mengalami kenaikan sebesar 28,6 persen HDF masih tetap mendapat keuntungan. Ketika usaha melakukan pengembangan usaha dengan menambah jumlah populasi ayam untuk meningkatkan produktivitas, dilihat dari sisi analisis finansial usaha ini masih layak untuk dijalankan.

\section{Saran}

Beberapa saran yang dapat diberikan sebagai hasil dari analisis yang dilakukan terhadap usaha ayam ras petelur pada $H$. Dofir Farm adalah sebagai berikut:

a. Berdasarkan analisis yang telah dilaksanakan maka H. Dofir Farm dapat melaksanakan pengembangan usahanya yaitu peningkatan produksi telur dengan menambah jumlah kandang dan ayam petelur dengan memanfaatkan lahan yang belum terpakai secara 
optimal oleh perusahaan, serta permintaan pasar yang masih belum terpenuhi cukup besar merupakan peluang bagi perusahaan.

b. Perusahaan harus menjaga produktivitas agar produksinya tidak mengalami penurunan. Untuk itu semua pekerja harus diberi arahan yang tegas dan kepala kandang harus selalu mengecek keadaan peternakan secara rutin. Dalam hal ini koordinasi antara kepala kandang dan pekerja sangat dibutuhkan.

c. Sebaiknya perusahaan tetap mengupdate informasi-informasi terbaru yang berkaitan dengan peternakan mengenai penyakit yang sedang terjadi serta cara penanggulangannya. Selain itu tetap mengecek perkembangan terbaru dari segi hargaharga baik harga input maupun output agar apabila ada perubahan perusahaan dapat segera mengatasi. Perkembangan teknologi baru juga perlu dipertimbangkan oleh perusahaan agar dengan adanya teknologi yang modern perusahaan dapat mengoptimalkan dan mengefisienkan kegiatan usaha.

\section{DAFTAR PUSTAKA}

Achmanu dan Muharlien., 2011. Ilmu ternak Unggas. UB Press. Malang

Amrullah, I. K. 2007. Nutrisi Ayam Broiler. Cetakan ke-1. Lembaga Satu Gunungbudi. Bogor.

Amrullah, I. K. 2007. Nutrisi Ayam petelur. Cetakan ke-1. Lembaga Satu Gunungbudi. Bogor.

Boediono. 2002. Ekonomi Mikro Seri Sinopsis Pengantar Ilmu Ekonomi No.1 Edisi Kedua Cetakan ke-23. Badan Penerbit Fakultas Ekonomi. Universitas Gadjahmada. Yogyakarta

Cahyono.1995. Beternak Ayam Buras dalam Budidaya Ayam Buras. CV. Aneka. Yogyakarta.

Dinas Peternakan Propinsi Jawa Timur., 2013. Data Statistik Populasi Ternak Ayam Kabupaten Tulungagung di Jawa Timur. www.disnak.jatimprov.go.id/web/layananpublik/datastatistik. diakses 12 Juli 2015

Dinas Peternakan dan Perikanan Kabupaten Tulungagung. 2014. Perkembangan Populasi Ternak ( Ekor ) Tahun 2009-2014. Tulungagung: Dinas Peternakan dan Perikanan Kabupaten Tulungagung.

Dinas Peternakan Propinsi Jawa Timur. 2014. Kontribusi Produk Telur 2010. Jawa Timur: Dinas Peternakan Propinsi Jawa Timur.

Direktorat Jendral Peternakan. 2014. Statistik Peternakan. Jakarta: Direktorat Jendral Peternakan.

Endang, S., S. Darana dan I. Setiawan., 2011. Implementasi Teknologi Semi ClosedHousesystem Pada Performan Ayam Broiler Di Test Farm Sustainable Livestock Techno Park, Kampus Fakultas Peternakan Universitas Padjadjaran, Jatinangor. Seminar Nasional Teknologi Peternakan dan Veteriner 2011 hal 362 - 366 
Ginting, A.B. 2006. Kontribusi Usahatani Padi dan Sapi Potong terhahadap Pendapatan Rumah tangga Petani di Kecamatan Purwodadi Kabupaten Grobogan Propinsi Jawa Tengah. VISI (2013) 21 (2) 1306-13014.

Hernanto, F. 1993..Ilmu Usaha Tani dalam Pembangunan Pertanian. PT. Penebar Swadaya. Jakarta

Kadariah, K.L G, 1986. Pengantar Evaluasi Proyek Edisi Revisi dalam Analisi Ekonomis. Jakarta: Universitas Indonesia Press.

Kay, R. D, W. M. Edward, and P. A. Duffy. 2004. Farm Management. macGraw- Hill Inc. New York.

Lubis, M. 2001. Industri Perunggasan: Memadukan Pertumbuhan dan Pemerataan. Forum Penelitian Agro Ekonomi, 20(1): 50-57

Mubyarto. 2000. Pengantar Ekonomi Pertanian. Cetakan keempat. LP3ES, Jakarta.

Rasyaf, M., 2008. Panduan Beternak Ayam Petelur. Jakarta: Penebar Swadaya.

Sudarmono. 2003. Strategi kemitraan usaha dalam rangka peningkatan daya saing agribisnis cabai merah di Jawa Tengah. Seminar nasional peningkatan daya saing agribisnis berorientasi kesejahteraan petani. Bogor, 14 Oktober 2009. Pusat Analisis Sosial Ekonomi dan Kebijakan Pertanian Badan Penelitian dan Pengembangan Pertanian. Departemen Pertanian. hlm 31-38

Sodiq, R. 2012. Pengantar Ekonomi Pertanian. Penerbit Andi. Yogyakarta.

Soekartawi. 2002. Prinsip Dasar Ekonomi Pertanian Teori dan Aplikasi. PT Raja Grafindo Persada. Jakarta.

Salam. 2009. Analisis Profitabilitas, Break Even Point Dan Payback Periode Pada Usaha Peternakan Sapi Potong. Studi Kasus Pada Usaha Peternakan Sapi Potong "Didik Farm" Di Desa Torongrejo Kecamatan Junrejo Kota Batu. SKRIPSI. Fakultas Peternakan Universitas Brawijaya. Malang

Supadi dan A. R. Nurmanaf., 2008. Pendapatan Dan Pengeluaran Rumah Tangga Pedesaan dan Kaitannya dengan Tingkat Kemiskinan. Pusat Analisis Sosial Ekonomi dan Kebijakan Pertanian, Bogor 